\title{
Islam, Etika Hukum dan Legal Culture
}

\author{
Yusdani
}

The main problem of Indonesia as a nation is a multidimensional crisis. This problem emerges because of misleading management of this state. The misleading management drives many cases, for instance corruption culture. The corruption denotes main problem in this nation building. Meanwhile when Indonesia towards reformation era since 1998, paying attention to law action and law enforcement is more than that of jurisprudence. Instead, it is still rarely the investigation of jurisprudence regarding religion and real culture of this nation. Because of Indonesian are religious nation, the religious leaders in Indonesia can contribute to formulate the ethic of law material, the ethic of law enforcement, and that of law institution.

Kata kunci: hukum, agama, etika, dan korupsi.

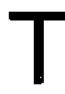
ak dapat dipungkiri bahwa persoalan fundamental bangsa yang sedang dihadapi Indonesia dewasa ini adalah keterpurukan dan krisis multidimensional. Persoalan ini muncul diakibatkan oleh banyaknya praktek-praktek penyeleweng-an dalam pengelolaan Negara yang tidak bertanggungjawab dan tidak dapat dibenarkan oleh etika dan moral. Salah satu bentuk penyelewengan itu adalah korupsi. Dalam sejarah perjalanan bangsa ini, kelihatannya korupsi telah menjadi sebuah penyakit yang hampir tak pernah sirna. Korupsi seolah-olah tak mengenal waktu dan rezim pemerintahan. Rezim telah berganti, tetapi budaya korupsi masih terus melaju. Dengan demikian, pantas bangsa Indonesia menyebut bahwa korupsi sebagai problema utama dalam pembangunan masa depan bangsa. ${ }^{1}$

Salah satu upaya dan solusi yang untuk memberantas korupsi di atas adalah menegakkan supremasi hukum. Akan tetapi ketika bangsa Indonesia euforia memasuki masa reformasi, ilmu hukum belum banyak tersentuh. Ketika ada pembicaraan mengenai hukum yang menjadi sorotan adalah praktik hukum, dan lebih fokus lagi penegakan hukum. Hampir belum pernah terdengar secara wajar pembahasan atau perdebatan mengenai hukum kaitannya dengan agama dan budaya riil masyarakat Indonesia. ${ }^{2}$

IImu hukum berbeda sekali dengan disiplin lain, seperti sosiologi, antropologi, bahkan juga ekonomi, terlebih lagi politik. Kajian mengenai beberapa disiplin ini telah tereformasi secara signifikan, meskipun belum menampakkan sosok "identitas"-nya. Akibatnya, hukum di Indonesia lebih sering

1 Haidar Bagir ( 2003), "Gagalnya Pendidikan Agama," Harian Kompas (Opini) Jumat, 28 Februari 2003.

${ }^{2}$ A Qodri Azizy (2005), "Menggagas IImu Hukum Indonesia" Harian Republika (opini) Sabtu 15 Januari 2005 
menjadi korban kritikan, bahkan juga hujatan oleh pelbagai pihak, tanpa ada solusi yang

ditawarkan untuk ke depan. Selama kenyataannya seperti itu, belum bahkan juga mungkin tidak akan muncul solusi peran hukum di Indonesia sesuai dengan harapan bangsa Indonesia. ${ }^{3}$

\section{Mengkaji Ulang Ilmu Hukum Indo- nesia}

Pembicaraan tentang hukum, sudah tentu melibatkan para pelaku hukumnya. Ketika para pelaku hukum menjalankan tugasnya seperti apa yang terjadi selama ini jelaslah tidak semata-mata kesalahan mereka. Bukankah mereka selalu mengatakan undang-undangnya memang berbunyi begitu. Dengan demikian, bukankah mereka mempunyai dasar dan landasan yang benar menurut ilmu hukum yang terjadi selama ini? Pendidikan hukum termasuk kurikulum serta sistem dan metode pendidikan belum menjadi sasaran evaluasi serius agar produknya sesual dengan harapan. Untuk itu, sudah seharusnya mengkaji ulang ilmu hukum. Bukan hanya semata-mata praktik hukum yang ada atau bukan pula hanya semata-mata menghujat pelaksana hukumnya. Memang banyak faktor yang harus dikaji serius, termasuk budaya hukum masyarakat, pendidikan hukum meliputi kurikulum, dan lain-lain), dan yang paling penting untuk segera dilakukan adalah membangun yang sesuai dengan budaya Indonesia. ${ }^{4}$

Secara singkat dapat dikatakan bahwa ilmu hukum yang dipelajari, diyakini, dan dipraktikkan bangsa Indonesia sampai sekarang pada hakikatnya merupakan IImu Hukum Belanda. Salah satu ciri terpenting dalam sistem hukum Belanda adalah aliran legal positivism. Suatu kekeliruan yang paling mendasar dalam kehidupan hukum di Indonesia, terutama sekali ketika pelaksana hukum memahami hukum atau undangundang secara harfiyah. ${ }^{5}$

Dalam kajian ilmu hukum, sistem hukum Belanda tergolong pengikut mazhab Roman Law System (istilah Prof Rahardjo sistem hukum Romawi-Jerman). Sistem ini dibentuk di benua Eropa yang penggodokannya sejak abad ke-12 dan 13, yang mendasarkan pada tersusunnya peraturan perundang-undangan. Menurut sistem ini, UU menjadi sumber utama dan hakim tidak boleh membuat keputusan yang berbeda dengan UU. ${ }^{6}$

Di dalam pasal $20 \mathrm{AB}$ disebutkan bahwa hakim harus mengadili berdasarkan UU. Dalam pandangan aliran Legisme abad $\mathrm{XIX}$, setelah Napoleon mengundangkan Civil Code-nya, berkembanglah anggapan bahwa UU adalah hukum itu sendiri. Civil Code bukan saja dianggap sempurna, juga sekaligus dianggap menghasilkan kepastian dan kesatuan hukum. Ini kemu-dian berkembang, bahwa UU adalah esensi hukum itu sendiri, hakim hanya mempunyai peran menerapkan UU meliputi peraturan perundangan dalam memberikan putusan hukum. $^{7}$

Kalau Roman Law System tersebut dipahami secara kaku, tidak ada kekeliruan hakim dalam memberikan keputusan. Dalam waktu bersamaan, juga tidak ada tanggung jawab yang dibebankan kepada hakim. Yang salah, keliru, tidak tepat, tidak adil, atau negatif lainnya adalah bunyi harfiah UU atau peraturan perundangan. legal

3 lbid.

4 lbid.

5 Satjipto Rahardjo (2000), IImu Hukum

(Bandung: Citra Aditya Bakti), hlm.237.

6 lbid.

7 lbid. hlm. 243 
maxim-nya, memang hukum atau peraturan perundangan berbunyi beigitu. Dengan demikian, terwujudnya proses dan praktik hukum di Indonesia yang dianggap salah atau tidak memuaskan, seperti yang selama ini dituduhkan, tidak dapat dibebankan kepada hakim secara keseluruhan, selama ilmu hukumnya belum dibenahi. Namun, paham hukum beberapa abad lalu di Belanda itu sendiri telah mengalami perubahan, penyesuaian, dan perbaikan sesuai dengan tuntutan jamannya. ${ }^{8}$

Jika diperbandingkan antara Roman Law System dan Common Law System kaitannya dengan hukum Indonesia. Realitas masyarakat Indonesia dan hukum kebiasaan yang ada bersama-sama dengan budaya dan agama, Indonesia lebih dekat dengan sistem Common Law dari pada dengan Roman Law. Common Law ini berasal dari Inggris sejak abad ke-11 sebagai hukum kota. Mulai abad ke-16 jenis hukum ini menyebar ke luar, termasuk ke Amerika Serikat. Sistem ini mendasarkan pada ketentuan hukum yang lebih dulu (judicial precedent) yang asalnya dari hukum tidak tertulis, bukan pada UU. Dengan kata lain, Common Law pada umumnya lebih berupa asas-asas (bukan peraturan tertulis) yang umum dan komprehensif berdasarkan rasa keadilan, pertimbangan akal dan pendapat umum yang dapat diterima. Lagi pula, asas-asasnya ditentukan oleh kebutuhan-kebutuhan masyarakat dan dapat berubah sesuai dengan perubahan kebutuhan tersebut. ${ }^{9}$

Jika diperhatikan lebih lanjut, sistem hukum Common Law tersebut lebih dekat dengan sistem hukum kebiasaan (customary law) di Indonesia, yang kemudian dibaca dengan Hukum Adat (adatrecht). Para ahli sudah banyak yang setuju bahwa Hukum Adat harus dipahami sebagai hukum yang hidup di masyarakat (living law) dan kebiasaan. Jadi, bukan dogma hukum dengan judul "hukum adat", yang berisi ketentuan tertulis. Sudah barang tentu, dalam perkembangannya juga mengenal hukum tertulis atau UU. Namun, esensi sistemnya masih tetap melekat pada peran hakim. Hakim tidak dituntut untuk menerapakan teks UU secara harfiah. Namun, lebih dituntut pada terwujudnya rasa keadilan, yang UU dijadikan sebagai alat untuk mencapai keadilan dimaksud.

Banyak buku telah membahas beberapa aliran teori hukum, yang biasanya selalu mencakup minimal tiga aliran: aliran legisme atau legal positivism. Hakim berperan hanya melakukan pelaksanaan

(Wetstoepassing); aliran Freie Rechtsbewegung. Hakim bertugas untuk menciptakan hukum (Rechtsschepping) dan sama sekali tidak terikat UU. Ini kebalikan yang pertama; aliran Rechts-vinding. Hakim mempunyai kebebasan yang terikat (Gebonden-Vrijheid) atau keterikatan yang bebas (Vije-Gebonden-heid). ${ }^{10}$ Lalu teori hukum mana yang diikuti oleh indonesia? Selama ini aliran hukum Indonesia dianggap sebagai pengikut aliran legal positivism atau legisme. Namun, anggapan tersebut keliru. Aliran yang kedua juga sama sekali tidak tepat bagi Indonesia. Lalu apakah yang ketiga, yakni Rechtsvinding atau legal realism? Ini juga masih kurang, sehingga belum mencerminkan keaslian Indonesia. Oleh karena itu, perlu tambahan "plus". Indonesia atau hukum nasional harus mempertegas dirinya sebagai pengikut mazhab Rechtsvinding/LegalReal$i s m^{\prime 1}$-Plus. Dengan demikian, secara

s Ibid, him. 235.

${ }^{9}$ Ibid. hlm. 45.

${ }^{10}$ C.S.T. Kansil dan Christine S.T. Kansil (2000), Pengantar limu Hukum dan Tata Hukum Indonesia (Jakarta: Balai Pustaka) I: 158-60 
naturenya, di Indonesia yang sejak awal sudah ada sistem hukum kebiasaan ditambah lagi tuntutan keadilan, maka sistem inilah yang seharusnya dipertegas bagi Indonesia. ${ }^{12}$

Posisi Hakim dalam Penegakan Hukum di Indonesia

Di dalam Undang-Undang Ketentuanketentuan Pokok Kekuasaan Kehakiman, secara jelas ditegaskan bahwa hakim-dan juga semua penegak hukum dan keadilan "wajib menggali, mengikuti, dan memahami nilai-nilai yang hidup dalam masyarakat". Ungkapan ini memberi peran besar bagi setiap hakim untuk memutuskan hukum atas dasar pemikiran yang mandiri dan bertanggung jawab untuk mewujudkan rasa keadilan dan kemaslahatan umum. ${ }^{13}$

Untuk sampai ke tingkatan dimaksud di atas, dalam hai-hal tertentu hakim harus lebih menggunakan pendekatan kontekstual, bukan tekstual. Ini berarti hakim dituntut untuk bukan saja aktif dan proaktif, namun juga sekaligus progresif. Sejak dua tahun lalu, Prof Satjipto Rahardjo telah berbicara beberapa kali tentang hukum progresif, sebagai hukum yang ideal. Mengapa ada plusnya? Dikatakan plus, oleh karena bukan saja masyarakat Indonesia adalah religius (sesuai dengan agama masing-masing), juga sudah masuk dalam sistem hukum Indonesia, bahwa setiap keputusan yang mempunyai nilai hukum (UUD, UU, dan keputusan pengadilan) selalu diawali dengan "Demi Keadilan Berdasarkan Ketuhanan Yang Maha Esa". Dalam penjelasan UU Kekuasaan Kehakiman dengan tegas urutan tanggung jawab hakim yang pertama sekali adalah kepada Tuhan Yang Maha Esa. Ungkapan ini pun perlu pembahasan dan kajian secara filosofis dan akademik, sebagai salah satu wujud sosialisasi yang mendasar. ${ }^{14}$
Dari uraian di atas, berarti jelaslah tidak cukup hanya menghujat praktik hukum, namun harus memberi solusi sampai dengan yang paling fundamental yaitu membangun Ilmu Hukum Indonesia (Indonesian Jurisprudence). Hal ini otomatis harus mengadakan evaluasi mendasar pula dalam kurikulum pendidikan hukum, baik lewat pendidikan formal maupun nonformal dengan bentuk pelatihan hukum. ${ }^{15}$

Keprihatinan pada kontribusi rendah ilmu hukum dalam turut serta mencerahkan bangsa untuk keluar dari krisis hukum, merupakan salah satu alasan Prof Dr Satjipto Raharjo SH untuk menggagas ilmu hukum progresif. "Ilmu pada dasarnya harus mampu memberi pencerahan pada komunitas yang dilayani. Untuk memenuhi peran itulah, ilmu hukum dituntut untuk menjadi progresif," papar Satjipto pada Seminar Nasional Menggagas IImu.Hukum (Progresif) Indonesia di Hotel Patra Jasa, Semarang. Dia menegaskan, selain undang-undang, moral juga bisa dijadikan sumberhukum. ${ }^{16}$

Para akademisi, aparat kejaksaan, pengadilan negeri dan agama, Satjipto juga

11 Jeffrie Murphy dan Jules (1984), The Philosophy of Law (New Jersey : Rowman \& Allanheld), him.22-42.

12 A. Qodri Azizy(2002), Eklektisisme Hukum Nasional Kompetisi antara Hukum islam dan Hukum Umum ( Yogyakarta: Gama Media), him.214.

${ }^{13}$ Undang-Undang Ketentuan-ketentuan Pokok Kekuasaan Kehakiman Undang-undang No 35 tahun 1999 perubahan dari UU No 14 tahun 1970.

${ }^{14}$ Satipto Rahardjo (2004), "Moral dapat Jadi Sumber Hukum," Harian Suara Merdeka Kamis 9 Desember 2004.

15 A. Qodri Azizy (2005), Menggagas... Harian Republika 15 Januari 2005. 
mengkritik sebagian orang yang selalu mengutarakan keticakpuasannya terhadap aparat hukum, seperti hakim, jaksa, dan pengacara. Kenapa tidak pernah mengkritik pendidikan hukum? Bukankah mereka (hakim, jaksa, dan pengacara) iulusan fakultas hukum?" tandasnya. Karena itulah, dia berharap ilmu progresif yang kini coba diperkenalkannya dapat diterapkan di fakultas-fakultas hukum yang ada di Indonesia. Dengan menerapkan ilmu hukum progresif, lanjut dia, penegakan hukum tidak semata-mata dilandasi oleh peraturan dan undang-undang, namun juga tingkah laku. "Undang-undang itu buatan manusia, jadi pasti ada cacatnya dan sewaktu-waktu harus dikoreksi. ${ }^{17}$

Menurut Satjipto, hakim di Indonesia hanya ada satu macam, yaitu hakim yang memeriksa dan mengadili. Namun perlu dibedakan juga, ada hakim yang memeriksa, lalu menanyakan pada hati nuraninya, dan kemudian mencari undangundangnya. Yang kedua, hakim yang menanyakan perutnya dulu, baru kemudian mencari undang-undang yang akan dipakai untuk nengesahkan keputusannya. Dia berpendapat, Bismar Siregar dan Busthanul Arifin (keduanya mantan hakim agung) termasuk golongan pertama. Di sini, moral juga dapat menjadi sumber hukum. Jangan ragu-ragu untuk menggunakan hukum secara kreatif, sehingga keadilan dapat ditegakkan. ${ }^{18}$

\section{Islam dan Moralitas Hukum di Indonesia}

Lapangan hukum yang dapat dimasuki oleh Islam sebagai salah satu agama yang dianut oleh mayoritas bangsa Indonesia dalam pembangunan hukum nasional, antara lain materi hukum sampai dengan etikanya, baik etika materi hukum, etika penegak hukum, maupun etika kelembagaan itu sendiri. Pembicaraan tentang etika hukum selama pemerintahan Orde baru, tampaknya tidak pernah menjadi wacana yang serius, apalagi menjadi penekanan dalam pembinaan hukum nasional. Barangkali karena kenyataan seperti inilah, hukum Indonesia sangat jauh dari idealitas yang seharusnya. Bukan saja tidak terjadi penegakan hukum, seperti yang disaksikan selama ini, tetapi dalam beberapa hal esensi hukum itu sendiri kurang mencerminkan nilai-nilai etika dan lebih mengedepankan pada formalisme hukum. ${ }^{19}$

Hukum dan keadilan tidak dapat dipisahkan, sehingga penerapan hukum tidak harus selalu bersifat formalitas lahiriah tanpa menampung keadilan yang sebenarnya. Dengan demikian, etika sangat dibutuhkan. Di samping itu, tanggung jawab hakim untuk menghasilkan putusan pengadilan yang benar-benar mewujudkan rasa keadilan itu akan erat kaitannya dengan Islam, sebagai agama yang bukan saja mempunyai konsekuensi dan tanggung jawab secara administratif di dunia namun juga mempunyai konsekuensi pahala dan dosa di akhirat kelak.

Berbicara mengenai etika, hukum tanpa etika sama artinya bukan hukum atau bahkan sama artinya dengan kezaliman. Lebih jauh lagi, karena etika tidak menjadi perhatian, para penegak hukum sama sekali jauh dari nilai-nilai etika itu. Seberapa besar

16 Ibid.

17 Satjipto Rahardjo (2004), "Pemberantasan Korupsi yang Progresif," Harian Suara Merdeka Selasa,28 Desember 2004.

$18 \mathrm{lbid}$.

$19 \mathrm{lbid}$. 
atau banyak etika hukum dijadikan mata kuliah di perguruan tinggi, baik di fakultas hukum, fakultas syari'ah, atau di fakultas lain, seperti filsafat atau bahkan lainnya, merupakan tanda sekaligus bukti seberapa serius etika hukum diperhatikan. Padahal di negara-negara Barat yang biasanya disebut sebagai negara sekular, nilai-nilai etika menjadi diskursus sehari-hari, termasuk etika hukum.

Buku-buku mengenai etika hukum, di samping etika penegaknya, sangat banyak. Keadaan seperti inilah yang terjadi di Indonesia selama puluhan tahun, yang kemudian menghasilkan krisis hukum dalam konteks kolusi., korupsi dan nepotisme yang sangat populer itu. Jadi kebobrokan hukum merupakan salah satu sebab kehancuran bangsa Indonesia keseluruhan. ${ }^{20}$

Selain etika hukum, ada pula beberapa topik lain yang berkaitan dengan hukum, yang selama ini seolah lepas dari kajian serius ketika membahas hukum nasional, seperti budaya hukum (legal culture). Ketika membahas budaya hukum ini juga tidak dapat lepas dari agama (Islam). Hal ini merupakan topik kajian hukum kaitannya dengan Isiam yang selama ini belum tersentuh. ${ }^{21}$

\section{Kontribusi Hukum Islam}

Jika diamati masyarakat Istam Indonesia, khususnya para tokoh muslim yang terlibat dalam pembahasan mengenai pemberlakuan hukum Islam di Indonesia, setidaknya ada dua kelompok, yaitu kelompok yang menekankan pada pendekatan normatif (formalisme) dan kelompok yang menekankan pada pendekatan kultural (budaya).

Pendekatan diatas sebagai perwujudan kehidupan politik dàri masing-masing kelompok, atau justru sebaliknya, :-yakni bahwa cermin politik mereka sebagai:wujud keyakinan terhadap jenis pendekatan tersebut. Hal ini juga sekaligus sebagai jawaban dari persoalan bagaimana penerapan hukum Islam, ketika disepakati bahwa hukum Islam merupakan salah satu darj tiga bahan baku dalam pembinaan hukum nasional. Penjelasan berikut ini akan diungkapkan baik pendekatan formal maupun kultural. ${ }^{22}$

Pertama, pendekatan formal (normatif). Menurut pendapat ini, hukum Islam harus diterapkan kepada mereka yang sudah mengucapkan dua kalimah syahadah atau sudah masuk Islam. Istilah hukum Islam tidak akan populer, kecuali berarti bahwa mereka yang beragama Islam Islam dengan harus menjalankan atau dipaksakan untuk menerima hukum Islam dalam kehidupan sehari-hari. Oleh karena itu, proses kehidupan politik, termasuk partai politik, adalah dalam rangka atau sebagai alat untuk menerapkan hukum Islam secara normatif dan formal ini. Konsekuensinya, pelaksanaan Piagam Jakarta menjadi persoalan besar dan serius yang harus selalu diperjuangkan, oleh karena merupakan satu-satunya cara untuk penerapan hukum Islam secara formal kalau perlu dipaksakan-di negara Indonesia.

Jika ditarik ke atas lagi dari sisi ekstrimitas, pendekatan normatif tersebut menjadi skriptualis dan tekstualis yang biasanya kurang mempertimbangkan kontekstual dan lingkungan sosiologis. Pada dasarnya pendekatan normatif tidak terlalu jelek jika akan dapat diposisikan sebagai pengontrol. Namun, jika berlebihan

20 lbid. him.167-168.

21 Ibid. hlm. 168.

${ }^{22}$ A. Qodri Azizy,Eklektisisme...hlm.194. 
akan sampai pada skriptualis dan pemaksaan tersebut. Sampai batas ini, upaya pemberlakuan hukum Islam tidak merupakan jawaban karena cenderung pada pemaksaan secara formal ideologis. Dan jika pendekatan ini yang diterapkan, persoalan yang muncul, adalah hukum Islam yang mana yang dimaksud?

Pertanyaan di atas sangat serius, terutama sekali ketika ditemukan kenyataan terjadinya perbedaan pendapat tentang hukum Islam itu sendiri. Persoalan seperti inilah yang sering terjadi sebagai ekses upaya islamisasi di beberapa negara di Timur Tengah yang kemudian hampir tidak pernah selesai.Tampaknya pertanyaan hukum Islam yang mana ini yang akan selalu muncul ke permukaan, seandainya perjuangan menerapkan Piagam Jakarta itu berhasil. Persoalan tersebut bukan masalah kecil, namun dapat menjadi masalah serius, terutama sekali ketika tidak dapat disatukan dalam menerima definisi tentang hukum Islam itu sendiri.

Kedua, Pendekatan kultural. Menurut pendapat ini, yang terpenting bukan formalisme penerapan hukum Isiam atau dengan pendekatan normatif ideologis. Namun penyerapan nilai-nilai hukum Islam ke dalam masyarakat itulah yang lebih penting. Barangkali dapat dijadikan contoh pendekatan yang kedua ini adalah ungkapan K. H. M. A. Sahal Mahfudh. Menurutrnya, " terciptanya hukum yang ideal dalam masyarakat madani dengan demikian harus dimulai juga dengan menyerap nilai-nilai hukum universal tersebut di atas dalam kerangka kemasyarakatan yang proporsional".

Nilai-nilai hukum universal yang dimaksudkan itu meliputi: keadilan, kejujuran, kebebasan, persamaan di muka hukum, perlindungan hukum terhadap masyarakat tak seagama, dan menjunjung tinggi supremasi hukum Allah. Maksudnya adalah bahwa 'nilai tersebut harus diupayakan tertanam dan terimplementasikan dalam segala unsur masyarakat madani, mulaj dari sistim kelembagaan dan unsur masyarakat pendukungnya". Dengan istilah penyerapan nilai, berarti bahwa prosesnya itu bersifat kultural, bukan pemaksaan secara normatif. Dengan pendekatan secara kultural seperti ini, K.H. Sahal yakin "akan memperkecil kendala yang ada pada tahap implementasi". Oleh karena itu, menurut K. H. Sahal "labelisasi yang sering menimbulkan sikap antipati dan kecurigaan dari kalangan masyarakat juga hendaknya diminimalkan". Setelah menguraikan cukup panjang dalam artikel berjudul "Peranan Hukum Islam dalam Menciptakan Masyarakat Madani Indonesia", K.H.M.A. Sahal Mahfudh lebih jauh lagi mengatakan sebagai berikut:

Menciptakan masyarakat madani dalam konteks ke-Indonesiaan dari kaca mata hukum Islam, dengan demikian tidak "dengan" atau "tanpa" hukum Islam, namun lebih kepada mempertimbangkan dan menyerap nilai-nilai moral positif yang terkandung dalam hukum Islam itu sendiri. Menerapkan hukum Islam dalam arti formalisasi hukum Islam terkadang belum merupakan solusi terbaik bagi proses formulasi hukum yang ideal bagi sebuah masyarakat madani. Demikian pula, eliminasi hukum-hukum yang ada dalam masyarakat, khususnya hukum Islam dalam proses tersebut juga bukan merupakan langkah yang bijaksana, karena bagaimana keberadaannya, baik sebagai sebuah nilai maupun sebagai sebuah peraturan yang yang beriaku tetap mendapatkan legitimasi yang kuat dalam masyarakat Indonesia. Meskipun demikian, ruang gerak bagi proses berkembangnya 
hukum-hukum yang ada di Indonesia, terutama hukum Islam, harus tetap dibiarkan leluasa. Hal demikian ini untuk merangsang agar hukum-hukum tersebut bisa lebih berkembang dinamis yang pada gilirannya juga akan memberikan sumbangan yang dinamis pula bagi perkembangan hukum Indonesia secara keseluruhan. ${ }^{23}$

Dari uraian tersebut jelaslah, posisi dan upaya serta pendekatan yang dilakukan oleh kelompok kedua atau kelompok yang menggunakan pendekatan kultural ini. Sudah barang tentu bagi kelompok kedua ini ungkapan dan sekaligus pendekatan pertama di atas dapat dikatakan berlebihan.

Untuk kajian hukum Isiam di Indonesia yang akan datang tidak menggunakan pendekatan normatif dan formalisme, namun juga tidak semata-mata dengan menggunakan pendekatan kultural secara longgar dan dalam pengertian yang pasif. Proses kultural memang suatu modal yang sangat berharga. Bahkan, di dalam kajian hukum pada umumnya, budaya hukum itu salah satu topik pembahasan yang serius secara akademik. Dan GBHN 1999 juga terjadi budaya hukum secara umum sebagai salah satu program selama lima tahun ke depan ini. Kajian dan penerapan hukum Islam dalam pembangunan hukum nasional dapat terjadi bajk dengan pendekatan normatif maupun dengan pendekatan kultural, setelah mendapat justifikasi argumentasi keilmuan atau akademik dalam kajian hukum di Indonesia secara terbuka. Sudah barang tentu késemuanya itu dalam koridor demokratisasi dan pemeliharaan hak asasi manusia yang sangat mementingkan pada hak-hak individu, tanpa mengorbankan hak publik. Kesemuanya itu dalam rangka realisasi GBHN 1999, yang lebih tegas menjelaskan adanya sumber hukum nasional, salah satu sumbernya adalah hukum Islam, tanpa harus melibatkan Piagam Jakarta. ${ }^{24}$

\section{Penutup}

Sebagai akhir tulisan ini perlu dikemukakan, bahwa agar hukum di Indonesia lebih responsif dan progresif dalam menangani masalah kebangsaan termasuk kasus korupsi dewasa ini adalah sebagai berikut:-

Pertama, perlu mengkaji ulang ilmu hukum Indonesia yang mencakup evaluasi aliran hukum mana yang sesuai dengan budaya bangsa, pembaharuan sistem pendidikan hukum, kurikulum dan reformasi sistem pendidikan aparat penegak hukum.

Kedua, bahwa hakim dan juga semua penegak hukum dan keadilan 'wajib menggali, mengikuti, dan memahami nilainilai yang hidup dalam masyarakat". Ungkapan ini memberi peran besar bagi setiap hakim untuk memutuskan hukum atas dasar pemikiran yang mandiri dan bertanggung jawab untuk mewujudkan rasa keadilan dalam kehidupan masyarakat, bangsa dan negara.

Ketiga, untuk memperkuat penegakan hukum di Indonesia, periu dukungan agama, terutama Islam sebagai agama yang dianut mayoritas bangsa ini untuk memberikan kontribusi moral dan etiknya dalam sistem pendidikan bangsa secara umum dan khususnya dalam pembinaan integritas kepribadian aparat penegak hukum di Indonesia.

${ }^{23}$ K.H. M.A. Sahal Mahfudh. 2001. "Peran Hukum Ișam dalam Menciptakan Masyarakat Madani Indonesia", Makalah Disampaikan dalam Diskusi di Pascasarjana IAIN Walisongo Semarang pada tanggal 27 September 2001. 24 ibid. hlm.198-199 
Topik: Agama dan Teologi Populis Transformatif

Keempat, pengembangan kajian hukum Islam di Indonesia untuk lebih bersifat kultural. Di samping itu, juga diorientasikan pada pengembangan dan penyerapan nilaj-nilai hukum Islam ke dalam sistem hukum nasional, kehidupan masyarakat, bangsa, dan negara.

\section{Daftar Pustaka}

Azizy, A. Qodri (2002), Eklektisisme Hukum Nasional Kompetisi Antaar Hukum Islam dan Hukum Umum .Yogyakarta :Gama Media.

,(2005), " Menggagas IImu Hukum Indonesia" Harian Republika (opini) Sabtu 15 Januari 2005

Bagir, Haidar (2003), "Gagalnya Pendidikan Agama," Harian Kompas Opini) Jumat, 28 Februari 2003

Kansil, C.S.T. dan Christine S.T. Kansil ( 2000), Pengantar limu Hukum dan Tata Hukum Indonesia. Jakarta: Balai Pustaka.

Mahfudh, K.H. M.A. Sahal (2001), "Peran Hukum Islam dalam Menciptakan Masyarakat Madani Indonesia",
Makalah Disampaikan dalam Diskusi di Pascasarjana IAIN Walisongo Semarang pada tanggai 27 September 2001.

Murphy, Jetfrie dan Jules (1984), The Philosophy of Law. New Jersey : Rowman \& Allanheld

Radhie, Teuku Muhammad (1983), Peranan Hukum islam Dalam Pembinaan Hukum Nasional. Yogyakarta : TTP

Rahardjo, Satjipto (1980), Hukum dan Masyarakat. Bandung: Angkasa (2004), "Moral dapat Jadi Sumber Hukum," Harian Suara Merdeka Kamis 9 Desember 2004.

(2004), "Pemberantasan Korupsi yang Progresif," Harian Suara Merdeka Selasa,28 Desember 2004. (2000), Ilmu Hukum. Bandung: Citra Aditya Bakti

Undang-Undang No. 14 Tahun 1970 Undang-Undang No. 35 Tahun 1999 